Original Research

\title{
Functional Characteristics of a Grass Sward as per an Athletic Field at the University of Warmia and Mazury in Olsztyn
}

\author{
Kazimierz Grabowski ${ }^{1 *}$, Stefan Grzegorczyk ${ }^{1}$, \\ Andrzej Lachacz ${ }^{2}$, Marzenna Olszewska ${ }^{1}$ \\ ${ }^{1}$ Department of Grassland and Green Space Management, Faculty of Environmental Management and Agriculture, \\ University of Warmia and Mazury in Olsztyn, Poland \\ ${ }^{2}$ Department of Soil Science and Land Reclamation, Faculty of Environmental Management and Agriculture, \\ University of Warmia and Mazury in Olsztyn, Poland
}

Received: 27 September 2019

Accepted: 30 January 2020

\begin{abstract}
Our study was conducted in 2013-2017 on the main sports field of the Department of Physical Education and Sport of the University of Warmia and Mazury in Olsztyn. The examined field was established in the 1950s. The following sward characteristics were evaluated on a 9-point scale in accordance with the methodology recommended by the Research Center for Cultivar Testing (COBORU): overwintering success (spring), density, color and the overall quality of the sward (spring, summer and fall). The species composition of the sward, plant health, functional characteristics of the sward, and soil compaction were also determined.

An increase in soil compaction, a decrease in the sward's functional characteristics and changes in the species composition of grass were noted after five years of field use for various disciplines of professional sports. The sward was characterized by varied overwintering success, high density (particularly in summer), green and fresh green color, very low prevalence of fungal diseases, and satisfactory or good visual merit. The proportion of Lolium perenne L. decreased, whereas the proportions of the undesirable species Pоа апnиа L. and dicotyledonous weeds increased in the analyzed sward.

The condition of the evaluated sward was influenced by loading (field exploitation), increased soil compaction, and deterioration in the physicochemical properties of soil, as well as the applied maintenance treatments and weather conditions during the study.
\end{abstract}

Keywords: athletic field, sward functional characteristics, species composition of sward

*e-mail: kazikg@uwm.edu.pl 


\section{Introduction}

Athletic fields should fulfill rigorous requirements. Grass species that compose the sward should maintain durability during intense use of various disciplines of professional sports. Sport swards ought to be short, dense, and flexible, have dark green color and be resistant to trampling and to wear and tear, and the main requirement - it should ensure a harmless environment for athletes, regardless of changing weather conditions [1-7]. Many factors affect the quality of a sport sward, including the type of soil material, plant species and the variety of grasses used for seed mixtures, intensity of usage, and applied cultivation activities. For the establishment of sport swards, the valuable plants are species and cultivars of lawn grasses resistant to spring and autumn frosts as well as resistant to drought periods in the summer. The occurrence of the above-mentioned weather phenomena reduce the vitality of plants and have a negative effects on field appearance. Among grass species that are the most frequently used for sport fields are Poa pratensis L., Lolium perenne L. and Festuca rubra L. The excessive compaction of the upper layer of mineral soil is the main reason behind sward degradation. This is concomitant with the decrease of sward density and reduction of share of lawn grasses and expansion of undesirable plant species (weeds) [8-13]. Moreover, densification of topsoil hampers the development of root systems, and as a result grasses are susceptible to various environmental stresses. The aim of this study was to determine the changes of functional characteristics and species during five years of exploitation of athletic fields at the University of Warmia and Mazury in Olsztyn.

\section{Materials and Methods}

The study was conducted on the main sports field of the Department of Physical Education and Sport of the University of Warmia and Mazury in Olsztyn. The field was established in the $1950 \mathrm{~s}$. The field was renovated in fall 2002 by direct seeding. Grass was mowed to a height of approximately $2 \mathrm{~cm}$, and green matter was removed. Before sowing, the field was fertilized with Yara Mila Complex at $200 \mathrm{~kg} \cdot \mathrm{ha}^{-1}$. A sports grass seed mixture was cross-sown at $250 \mathrm{~kg} \cdot \mathrm{ha}^{-1}$ using a Vredo disc seeder (the Netherlands). The seed mixture of lawn grass species had the following composition:

- Lolium perenne cv. Niga - $20 \%$

- Lolium perenne cv. Nira - 20\%

- Poa pratensis cv. Bila - 20\%

- Poa pratensis cv. Prima - 20\%

- Festuca rubra cv. Nimba - 10\%

- Festuca rubra cv. Leo - 10\%

After sowing, the field was irrigated with sprinkles every 2-3 days at $5 \mathrm{~mm}$ per day and daily during drought. The field was mown twice to a height of 5-6 cm to eliminate weeds. Phosphorus (35 $\left.\mathrm{kg} \mathrm{P}_{2} \mathrm{O}_{5} \cdot \mathrm{ha}^{-1}\right)$ and potassium $\left(80 \mathrm{~kg} \mathrm{~K} \mathrm{O}_{2} \mathrm{O} \cdot \mathrm{ha}^{-1}\right)$ fertilizers were applied in early October.

In 2013-2017, the following sward characteristics were evaluated at 15 representative sampling sites on a 9-point scale (1 - unacceptable, 5 - satisfactory, 9 - highly desirable) in accordance with the methodology recommended by the Research Center for Cultivar Testing (COBORU) [1]: overwintering success (spring), density, color and the overall quality of the sward (spring, summer and fall). This sward valorization is based on the method developed in COBORU [1] as well as based on the visual and functional method by Turgeon [5], and it is similar and comparable to the methods of sward assessment applied by UEFA and FIFA, where visual and functional assessment of sward is carried out according to an 8-10-point scale (usually 9-point scale) [14]. The functional characteristics of the sward were determined with the following formula [1]:

$$
\mathrm{FC}=\Sigma(0.34 \times \mathrm{VM}+0.33 \times \mathrm{D}+0.33 \times \mathrm{C})
$$

...where:

FC - functional characteristics of the sward

$\mathrm{VM}$ - visual merit

D - sward density

C - sward color

Additionally, plant health and soil compaction were determined with a penetrometer. In the spring of every experimental year, $100 \mathrm{~g}$ samples of green matter were collected at five points across the field (along a diagonal line) for a detailed botanical analysis. Lawn grass species, other grasses and weeds were identified in the collected material. The proportions of different plant species in the collected samples were determined on a dry weight basis.

Samples of topsoil were collected in spring 2013 and analyzed to determine the following parameters: granulometric composition of soil (by the method proposed by Bouyoucos and modified by Casagrande and Prószyński) [15], organic matter content [16], hydrolytic acidity (by Kappen's method) [15], organic carbon content (by colorimetry) [15], content of plantavailable macronutrients and micronutrients ( $\mathrm{P}, \mathrm{K}$, $\mathrm{Mg}, \mathrm{Cu}, \mathrm{Mn}, \mathrm{Fe}$ and $\mathrm{Zn}$ ) in $0.5 \mathrm{~mol} \mathrm{HCl} \cdot \mathrm{dm}^{-3}$, calcium content by complexometric titration, and sodium content by flame photometry [16].

Mineral fertilizer (Yara Mila Complex, compound fertilizer) was applied twice: in early spring $\left(250 \mathrm{~kg} \cdot \mathrm{ha}^{-1}\right)$ and in fall $\left(150 \mathrm{~kg} \cdot \mathrm{ha}^{-1}\right)$. Nitrogen fertilizer was applied at the beginning of the growing season and then after every third mowing at $20-30 \mathrm{~kg} \mathrm{~N} \cdot \mathrm{ha}^{-1}$.

The sward was mowed at least once a week in May and June, and then every two weeks to a height of $3.0-3.5 \mathrm{~cm}$. Annual treatments were limited to dragging and rolling in spring. Sprinkling irrigation was applied during drought.

Weather conditions during the study are presented in Table 1. In 2013-2017, weather conditions were generally favorable for the growth and development of 
Table 1. Mean air temperature and sum of precipitation according to the meteorological station in Tomaszkowo, near Olsztyn.

\begin{tabular}{|c|c|c|c|c|c|c|c|c|c|c|c|c|c|c|c|}
\hline \multirow{2}{*}{\multicolumn{2}{|c|}{ Years }} & \multicolumn{12}{|c|}{ Months } & \multirow{2}{*}{$\begin{array}{l}\text { Mean for period } \\
\text { IV-IX }\end{array}$} & \multirow{2}{*}{$\begin{array}{c}\text { Yearly mean } \\
\text { I-XII }\end{array}$} \\
\hline & & I & II & III & IV & $\mathrm{V}$ & VI & VII & VIII & IX & $X$ & XI & XII & & \\
\hline \multirow{2}{*}{2013} & $\mathrm{t}$ & -4.6 & -1.1 & -3.5 & 5.9 & 14.8 & 17.5 & 18.0 & 17.4 & 11.3 & 8.9 & 5.0 & 2.3 & 14.2 & 7.7 \\
\hline & $\mathrm{p}$ & 44.1 & 22.6 & 18.1 & 28.5 & 54.5 & 61.2 & 121.9 & 37.6 & 101.1 & 16.0 & 18.0 & 27.7 & 404.8 & 551.3 \\
\hline \multirow{2}{*}{2014} & $\mathrm{t}$ & -4.0 & 1.2 & 5.1 & 8.8 & 13.0 & 14.4 & 20.4 & 17.1 & 13.6 & 8.7 & 3.7 & -0.4 & 14.6 & 8.5 \\
\hline & $\mathrm{p}$ & 48.4 & 8.1 & 57.7 & 26.0 & 32.7 & 50.8 & 37.3 & 86.1 & 25.9 & 15.1 & 34.0 & 61.8 & 258.8 & 483.9 \\
\hline \multirow{2}{*}{2015} & $\mathrm{t}$ & 0.4 & 0.5 & 4.2 & 6.7 & 11.8 & 15.5 & 17.5 & 19.8 & 13.5 & 6.1 & 4.8 & 3.4 & 14.1 & 8.7 \\
\hline & $\mathrm{p}$ & 46.8 & 6.8 & 45.1 & 38.2 & 29.7 & 29.5 & 81.9 & 14.3 & 63.8 & 19.4 & 84.5 & 56.6 & 257.4 & 516.6 \\
\hline \multirow{2}{*}{2016} & $\mathrm{t}$ & -4.0 & 2.3 & 3.0 & 7.4 & 13.7 & 17.1 & 18.1 & 17.1 & 13.6 & 6.1 & 2.4 & 0.8 & 14.5 & 8.1 \\
\hline & $\mathrm{p}$ & 24.7 & 57.1 & 21.6 & 28.8 & 56.9 & 69.3 & 130.4 & 70.4 & 21.1 & 104.3 & 84.8 & 41.1 & 376.9 & 710.5 \\
\hline \multirow{2}{*}{2017} & $\mathrm{t}$ & -3.4 & -1.4 & 4.0 & 5.7 & 12.1 & 15.7 & 16.8 & 17.4 & 12.8 & 8.7 & 3.9 & 1.8 & 13.4 & 7.8 \\
\hline & $\mathrm{p}$ & 20.2 & 47.6 & 45.3 & 59.1 & 25.1 & 74.5 & 107.6 & 63.1 & 168.1 & 114.9 & 42.4 & 35.2 & 497.5 & 803.1 \\
\hline \multirow{2}{*}{$\begin{array}{c}\text { Mean } \\
(2004-2018)\end{array}$} & $\mathrm{t}$ & -2.8 & -2.0 & 1.7 & 7.7 & 12.9 & 16.0 & 18.7 & 17.8 & 13.3 & 7.7 & 3.7 & 0.3 & 14.4 & 7.9 \\
\hline & $\mathrm{p}$ & 42.7 & 27.9 & 32.8 & 31.5 & 55.6 & 73.7 & 100.2 & 68.3 & 54.2 & 50.4 & 47.8 & 41.0 & 383.5 & 626.1 \\
\hline
\end{tabular}

$\mathrm{t}$ - temperature, ${ }^{\circ} \mathrm{C}$

$\mathrm{p}$ - precipitation, $\mathrm{mm}$

lawn grass. The average annual temperature exceeded the long-term average (2004-2018) in 2014, 2015 and 2016, and the average temperature during the growing season approximated the long-term average in all experimental years, excluding 2017. Total precipitation in the experimental years (January to December) and growing seasons (April to September) was highest in 2017, whereas 2014 and 2015 were the driest years.

January was the coldest year in all experimental years, excluding 2015. Ambient temperatures in February and March were generally higher than the long-term average. Higher temperatures led to rapid melting of snow cover, and below-zero temperatures were noted in early March. The growing season began in April, when the average temperature exceeded $+5^{\circ} \mathrm{C}$. Ambient temperature ranged from $11.8^{\circ} \mathrm{C}$ to $17.5^{\circ} \mathrm{C}$ in May and June. The highest temperatures were noted in July and August, and ambient temperature began to decrease gradually in September. Low temperatures in November and December inhibited plant growth.

Precipitation deficiency was low in January 2016 and 2017, in February 2014 and 2015, and in March 2013 and 2016 (Table 1). In April, precipitation levels approximated the long-term average, excluding in 2017 when rainfall was nearly twice higher than the long-term average. Precipitation was relatively low in May 2014, 2015 and 2017, in June 2015, in July 2014, in August 2013 and 2015, and in September 2014 and 2016. September was also characterized by high precipitation, which exceeded the monthly average $(54.2 \mathrm{~mm})$ by 2- to 3-fold. High precipitation was also noted in October 2016 and 2017, November 2015 and 2016, and December 2014 and 2015. In fall, weather conditions were generally favorable for the growth and development of lawn grass.
The results were processed statistically with Statistica 13.1, a statistics and analytics software package developed by StatSoft (2018) [17].

\section{Results and Discussion}

According to the classification of soil granulometric groups [18], the topsoil layer of the analyzed sports field was composed of loamy sand (Table 2). In topsoil, the content of skeleton particles was estimated at 3-13\% (sand fraction $78-83 \%$, silt fraction $14-20 \%$, clay fraction 2-4\%). The proportion of fractions with particle size below $0.02 \mathrm{~mm}$ ranged from $7 \%$ to $12 \%$ and exceeded the $8 \%$ content recommended by the standard [2] for sports fields. According to Pawluczuk and Grabowski [3], high contents of silt and clay fractions can obstruct the removal of excess rainwater from soil. Based on its granulometric composition, the analyzed substrate was classified as light soil.

The concentrations of plant-available nutrients in the substrate are presented in Table 3. The topsoil had a neutral $\mathrm{pH}$, which exceeded the optimal values for grass. Grasses thrive in habitats with a weakly acidic $\mathrm{pH}$ (5.5 to 6.5). According to Scheffer and Schachtschabel [19], an increase in soil $\mathrm{pH}$ to 7.5 decreases the content of plant-available iron, manganese and zinc. The average $\mathrm{C}: \mathrm{N}$ ratio of topsoil was determined at $11.98: 1$, which is indicative of satisfactory microbial activity.

Soil salinity was within the norm $\left(<1 \mathrm{~g} \cdot \mathrm{dm}^{-3}\right)$, and it did not limit the growth of grass. In a study by Zhu and Li [20], the application of humus in a sports field reduced soil salinity, increased microbial biomass and improved sward quality. 
Table 2. Granulometric composition of field lawn subsoil.

\begin{tabular}{|c|c|c|c|c|c|c|c|c|}
\hline \multirow{5}{*}{$\begin{array}{c}\text { Research } \\
\text { point } \\
\text { number }\end{array}$} & \multicolumn{6}{|c|}{ Fraction content $(\%)$} & \multirow{3}{*}{$\begin{array}{l}\text { Skeletal } \\
\text { fraction }\end{array}$} & \multirow{5}{*}{$\begin{array}{c}\text { Soil textural classes } \\
\text { acc. PTG* }\end{array}$} \\
\hline & Clay fraction & Silt fraction & & Sand & action & & & \\
\hline & Clay & Silt & $\begin{array}{l}\text { Very fine } \\
\text { sand }\end{array}$ & Fine sand & $\begin{array}{l}\text { Medium } \\
\text { sand }\end{array}$ & Coarse sand & & \\
\hline & \multicolumn{7}{|c|}{ Particle diameter (mm) } & \\
\hline & $<0.002$ & $0.002-0.05$ & $0.05-0.10$ & $0.10-0.25$ & $0.25-0.50$ & $0.50-2.00$ & $>2.00$ & \\
\hline 1 & 3 & 15 & 15 & 18 & 18 & 31 & 13 & Loamy sand \\
\hline 3 & 2 & 20 & 15 & 21 & 19 & 23 & 8 & Loamy sand \\
\hline 8 & 4 & 15 & 14 & 19 & 22 & 26 & 11 & Loamy sand \\
\hline 13 & 3 & 14 & 12 & 13 & 27 & 31 & 6 & Loamy sand \\
\hline 15 & 3 & 14 & 21 & 23 & 21 & 18 & 3 & Loamy sand \\
\hline Mean & 3 & 15.6 & 15.4 & 18.8 & 21.4 & 25.8 & 8.2 & - \\
\hline
\end{tabular}

* Particle size distribution and textural classes of soils and mineral materials - Classification of Polish Society of Soil Science 2008. Rocz. Glebozn. - Soil Sc. Ann., 2009.

The organic matter content of soil ranged from $3.43 \%$ to $6.55 \%$ and exceeded the norm for sports fields according to DIN 18035-4 criteria (Table 3). The organic matter content of soil should range from $1 \%$ to $3 \%$ to increase the soil's water-holding capacity. According to Kim [21], organic matter improves soil structure, aeration, moisture content, nutrient availability and ecosystem longevity. Adams and
Saxon [22] observed that excessive organic matter content in the root zone leads to macropore blockage and deterioration in the physical properties of soil, including drainage, aeration and water retention, which can restrict root formation and increase susceptibility to disease. According to Carrow [10], the organic matter content of topsoil in sports fields should not exceed $3-4 \%$.

Table 3. Chemical properties of field lawn subsoil.

\begin{tabular}{|c|c|c|c|c|c|c|}
\hline \multirow{2}{*}{ Specification } & \multicolumn{5}{|c|}{ Research point number } & \multirow{2}{*}{ Mean } \\
\hline & 1 & 3 & 8 & 13 & 15 & \\
\hline $\mathrm{pH}_{\mathrm{KCL}}$ & 7.20 & 7.30 & 7.25 & 7.20 & 7.20 & 7.23 \\
\hline $\mathrm{pH}_{\mathrm{H} 2 \mathrm{O}}$ & 7.46 & 7.68 & 7.50 & 7.52 & 7.47 & 7.53 \\
\hline $\mathrm{N}$-total $\left(\mathrm{g} \cdot \mathrm{kg}^{-1}\right)$ & 2.1 & 2.4 & 1.9 & 2.4 & 1.6 & 2.1 \\
\hline C-org. $\left(\mathrm{g} \cdot \mathrm{kg}^{-1}\right)$ & 23.8 & 22.8 & 20.2 & 38.0 & 19.9 & 24.9 \\
\hline Organic matter $(\%)$ & 4.10 & 3.93 & 3.48 & 6.55 & 3.43 & 4.30 \\
\hline $\mathrm{C}: \mathrm{N}$ & 11.4 & 9.5 & 10.6 & 16.0 & 12.4 & 11.98 \\
\hline Salinity $\left(\mathrm{g} \cdot \mathrm{dm}^{-3}\right)$ & 0.22 & 0.20 & 0.23 & 0.24 & 0.25 & 0.23 \\
\hline \multicolumn{7}{|c|}{ Content of available nutrients } \\
\hline $\mathrm{P}\left(\mathrm{mg} \cdot \mathrm{kg}^{-1}\right)$ & 79.8 & 77.1 & 77.1 & 66.3 & 77.1 & 75.5 \\
\hline $\mathrm{K}\left(\mathrm{mg} \cdot \mathrm{kg}^{-1}\right)$ & 78.8 & 74.1 & 83.0 & 62.3 & 74.7 & 74.6 \\
\hline $\mathrm{Ca}\left(\mathrm{mg} \cdot \mathrm{dm}^{-3}\right)$ & 801.0 & 740.0 & 730.0 & 710.0 & 860.0 & 768 \\
\hline $\mathrm{Mg}\left(\mathrm{mg} \cdot \mathrm{kg}^{-1}\right)$ & 61.0 & 74.0 & 67.0 & 60.0 & 61.0 & 64.6 \\
\hline $\mathrm{Na}\left(\mathrm{mg} \cdot \mathrm{dm}^{-3}\right)$ & 23.0 & 20.0 & 26.0 & 31.0 & 27.0 & 25.4 \\
\hline $\mathrm{Cu}\left(\mathrm{mg} \cdot \mathrm{kg}^{-1}\right)$ & 3.5 & 3.7 & 3.1 & 5.8 & 4.7 & 4.2 \\
\hline $\operatorname{Mn}\left(\mathrm{mg} \cdot \mathrm{kg}^{-1}\right)$ & 132 & 146 & 121 & 166 & 132 & 139 \\
\hline $\mathrm{Fe}\left(\mathrm{mg} \cdot \mathrm{kg}^{-1}\right)$ & 1000 & 1160 & 850 & 1200 & 950 & 1032 \\
\hline $\mathrm{Zn}\left(\mathrm{mg} \cdot \mathrm{kg}^{-1}\right)$ & 12.1 & 17.2 & 18.8 & 18.9 & 13.1 & 16.0 \\
\hline
\end{tabular}


In addition to humus content, soil fertility is also determined by the content of plant-available macronutrients and micronutrients [23]. In the analyzed samples, phosphorus content ranged from moderate (66.3 mg P. $\cdot \mathrm{kg}^{-1}$, sampling site 13$)$ to high $(79.8 \mathrm{mg}$ $\mathrm{P} \cdot \mathrm{kg}^{-1}$, sampling sites $1,3,8$ and 15$)$. Potassium content ranged from low (62.3 mg K. $\mathrm{kg}^{-1}$, sampling sites 3, 13 and 15) to moderate $\left(83.0 \mathrm{mg} \mathrm{K} \cdot \mathrm{kg}^{-1}\right.$, sampling sites 1 and 8). Calcium content was determined in the optimal range [23] at 710.0 to $860.0 \mathrm{mg} \mathrm{Ca} \cdot \mathrm{dm}^{-3}$. Magnesium content was high to very high $\left(60.0-74.0 \mathrm{mg} \mathrm{Mg} \cdot \mathrm{kg}^{-1}\right)$. Sodium content was relatively low (20-31 mg Na$\left.\cdot \mathrm{dm}^{-3}\right)$, and it did not exert a toxic effect on the growth and development of lawn grass species. Copper and zinc content was high, whereas manganese and iron levels were moderate in soil samples collected from all sites (Table 3).

The results of the study conducted in the Olsztyn Lakeland revealed considerable variations in the overwintering success, density, color and overall quality of the sward in the analyzed sports field. The examined sward differed in terms of overwintering success (4.1-6.2 points on the 9-point scale). This parameter was average to high in 2013-2014, average in 2015, and low to average in the remaining years of the experiment (Table 4). Overwintering success is difficult to determine in grasses due to considerable variations in the duration of the growing season. These variations can be attributed to low temperature, snow cover and the prevalence of winter diseases. According to Huang et al. [12], various abiotic stressors (drought, salinity, high and low temperatures) can compromise the appearance and functional characteristics of lawn grass. Therefore, the maintenance of grass sports fields in good condition poses a considerable challenge [24].

Sward density in the investigated sports field varied across the experimental years and seasons (Table 4). This parameter was high (average of 6.9 points on the 9-point scale) in the summer, and satisfactory to high in spring and fall. According to Anderson et al. [25], natural grass surfaces in sports fields are susceptible to mechanical damage caused by sports (such as rugby and soccer). Straw et al. [8] observed that variations in natural grass cover, resistance to mowing, surface hardness and uniformity affect playability and increase the risk of injury. Sward density influences the general appearance of sports fields, and it determines the persistence and adaptability of grass species to the local habitat conditions [26-28]. In sports fields, sward density is determined by substrate preparation, irrigation, fertilization, mowing frequency, intensity of use, maintenance treatments and weather conditions [5-7, 13]. According to Laudański et al. [29], visual merit is $70 \%$ determined by sward density, whereas color $(20 \%)$ and leaf fitness $(10 \%)$ are less important parameters.

Ford and Twomey [9] reported that natural grass cover decreases soil hardness in sports fields, even during drought. Athletic fields should be sown with grass species that ensure full grass cover throughout the growing season, in particular species and varieties that create resilient and dense swards: Lolium perenne L., Poa pratensis L. and Festuca rubra L. Grass also creates a softer surface for running in all sports disciplines [8].

Table 4. Utilizable values of sport field sward (mean \pm standard error).

\begin{tabular}{|c|c|c|c|c|c|c|}
\hline Season & Year & Overwintering & Compactness & Color & Healthiness & General aspect \\
\hline \multirow{5}{*}{ Spring } & 2013 & $6.2 \pm 0.3$ & $6.6 \pm 0.2$ & $4.3 \pm 0.3$ & $7.2 \pm 0.2$ & $6.4 \pm 0.1$ \\
\cline { 2 - 7 } & 2014 & $6.0 \pm 0.3$ & $6.5 \pm 0.3$ & $5.2 \pm 0.4$ & $6.5 \pm 0.3$ & $5.9 \pm 0.2$ \\
\cline { 2 - 7 } & 2015 & $5.3 \pm 0.3$ & $5.4 \pm 0.4$ & $5.1 \pm 0.4$ & $6.7 \pm 0.1$ & $5.3 \pm 0.3$ \\
\cline { 2 - 7 } & 2016 & $4.5 \pm 0.4$ & $5.1 \pm 0.3$ & $2.7 \pm 0.6$ & $7.4 \pm 0.1$ & $4.5 \pm 0.4$ \\
\cline { 2 - 7 } & 2017 & $4.1 \pm 0.2$ & $4.5 \pm 0.2$ & $3.3 \pm 0.4$ & $7.3 \pm 0.1$ & $3.7 \pm 0.2$ \\
\hline \multirow{5}{*}{ Summer } & Mean & $5.2 \pm 0.2$ & $5.6 \pm 0.2$ & $4.1 \pm 0.2$ & $7.0 \pm 0.1$ & $5.2 \pm 0.2$ \\
\cline { 2 - 7 } & 2013 & & $7.1 \pm 0.2$ & $6.3 \pm 0.2$ & & $6.3 \pm 0.2$ \\
\cline { 2 - 7 } & 2014 & & $7.7 \pm 0.2$ & $6.9 \pm 0.3$ & & $7.3 \pm 0.2$ \\
\cline { 2 - 7 } & 2015 & & $7.5 \pm 0.4$ & $5.2 \pm 0.6$ & - & $5.9 \pm 0.2$ \\
\cline { 2 - 7 } & 2017 & & $6.1 \pm 0.2$ & $5.0 \pm 0.5$ & & $5.7 \pm 0.2$ \\
\hline \multirow{5}{*}{ Autumn } & 2013 & & $6.3 \pm 0.3$ & $5.1 \pm 0.3$ & & $4.9 \pm 0.2$ \\
\cline { 2 - 7 } & 2014 & & $6.9 \pm 0.1$ & $5.7 \pm 0.2$ & & $6.0 \pm 0.1$ \\
\hline & 2015 & & $6.3 \pm 0.3$ & $5.5 \pm 0.3$ & & $6.1 \pm 0.2$ \\
\hline & 2016 & & $7.1 \pm 0.2$ & $6.1 \pm 0.4$ & & $6.8 \pm 0.2$ \\
\hline & 2017 & & $6.5 \pm 0.3$ & $5.3 \pm 0.5$ & & $5.8 \pm 0.2$ \\
\hline
\end{tabular}


In spring, the analyzed sward was grayish-green in color (average of 4.1 points on the 9-point scale) (Table 4). Fresh green color was observed in summer (average of 5.7 points on the 9-point scale) and fall (average of 5.3 points on the 9-point scale). In sports fields, dark green (emerald) grass is more visually appealing than light green grass [3, 30]. According to the literature, color stability during the growing season and the resistance of grass species (varieties) to environmental stressors that induce changes in color are the main determinants of visual merit. Turgeon [5] argued that grass color is affected primarily by species composition, mowing frequency, rate of fertilization, irrigation, and pest and disease control.

Sward health was evaluated based on the prevalence of plant diseases in 2013-2017. A phytopathological analysis revealed a low prevalence of disease ( 7.0 points on the 9-point scale) (Table 4).

The visual merit of sports fields is determined by numerous factors, including grass species and varieties, soil type, soil fertility, granulometric composition of soil, physicochemical properties of soil, intensity of use, maintenance treatments (irrigation, fertilization, mowing, pest and disease control), and weather conditions. The appearance of the sports field was evaluated as average (average of 5.2 points on the 9-point scale) in spring, and satisfactory to good in summer (average of 6.0 points on the 9-point scale) and fall (average of 5.7 points on the 9-point scale) (Table 4). During the study, the visual merit of the sports field was affected by variable weather conditions - in particular extreme temperatures and drought.

Visual merit is a synthetic measurement that accounts for genotype $\times$ environment interactions and reflects the species composition of grass (Table 4). According to Russi et al. [6], turf quality improved over time, whereas Brede [31] demonstrated that the aesthetic value of grass deteriorated in successive seasons and years of the experiment. Diesburg et al. [32] found that the visual merit of lawns is not a critical parameter in intensively used fields. The above author concluded that the functional characteristics of the examined field are determined by the persistence of the grass stand, which should uniformly cover the surface of the field, stabilize soil, reduce dust and mud, and eliminate weeds.

Sward density, color and general appearance are indicative of plant health, and they determine the visual merit of the lawn. The functional characteristics (FC) of a sward are determined based on the average values of three quality parameters: visual merit, density and color. In the analyzed sports field, the highest values of FC (5.8-6.6) were noted in the first years of the study (2013-2015), whereas significantly lower values (4.8-4.9) were observed towards the end of the experiment (Fig. 1). Similar results were reported by Wolski et al. [30].

Sward density, expressed as soil compaction, measured exceeded the norm for sports fields 1.3- to 2.0 -fold (1.5-fold on average) (Table 5), and it was

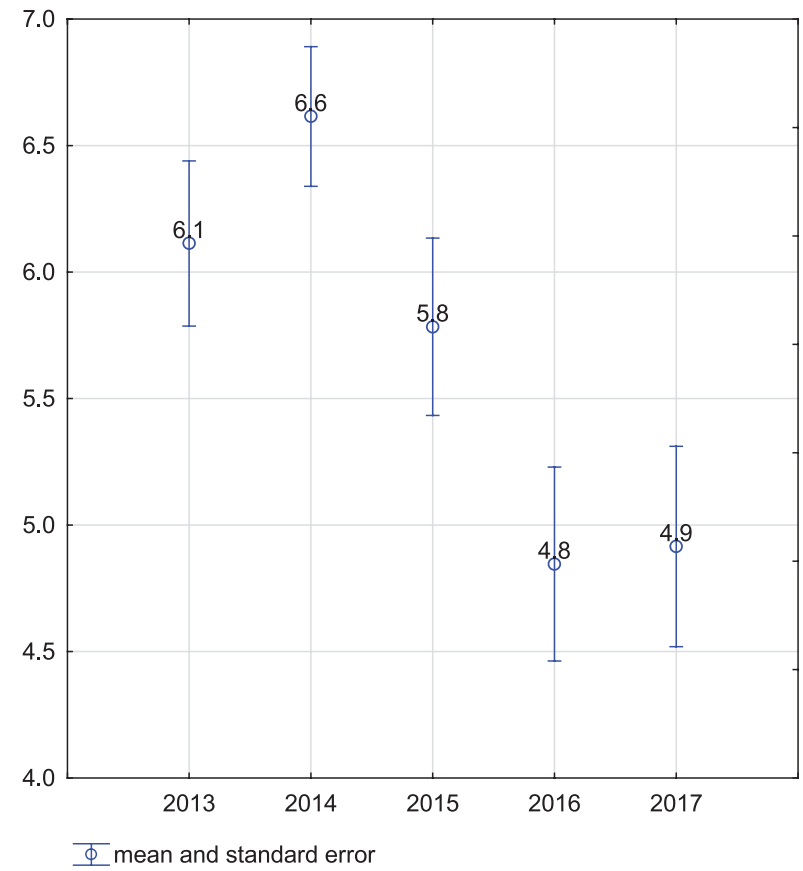

Fig. 1. Functional characteristics of sports grass (9-point scale).

highest in 2016. According to the literature, high topsoil compaction decreases permeability, inhibits healthy root development (by preventing roots from penetrating deeper soil horizons), and disrupts gas exchange and nutrient uptake. The management of high-quality swards in sports fields poses a considerable challenge $[5,7,13]$.

Sports fields are established on a layer of sand to minimize soil compaction [12]. According to Dixon [11] and Anderson et al. [25], sand improves drainage, but it lacks cohesive properties, and the stability of substrates exposed to load depends on frictional forces between particles. Another study [33] revealed that grasscovered surfaces are more resistant to compaction than bare land due to the unique properties of the soil fauna and the shock-absorbing effects of plant roots.

In the present study, the results of a detailed botanical analysis revealed that grass species were accompanied by monocotyledonous and dicotyledonous weeds

Table 5. Soil compaction (bar) (mean \pm standard error).

\begin{tabular}{|c|c|c|c|c|}
\hline Year & Mean & Minimum & Maximum & CV $(\%)^{*}$ \\
\hline 2013 & $18.5 \pm 1.2$ & 11 & 25 & 25.8 \\
\hline 2014 & $19.1 \pm 0.8$ & 14 & 25 & 15.9 \\
\hline 2015 & $20.5 \pm 0.6$ & 18 & 25 & 10.6 \\
\hline 2016 & $28.6 \pm 1.7$ & 20 & 40 & 22.5 \\
\hline 2017 & $20.7 \pm 0.8$ & 14 & 25 & 14.8 \\
\hline Mean & $21.5 \pm 0.6$ & 11 & 40 & 25.5 \\
\hline
\end{tabular}

$* \mathrm{CV}-$ coefficient of variation 


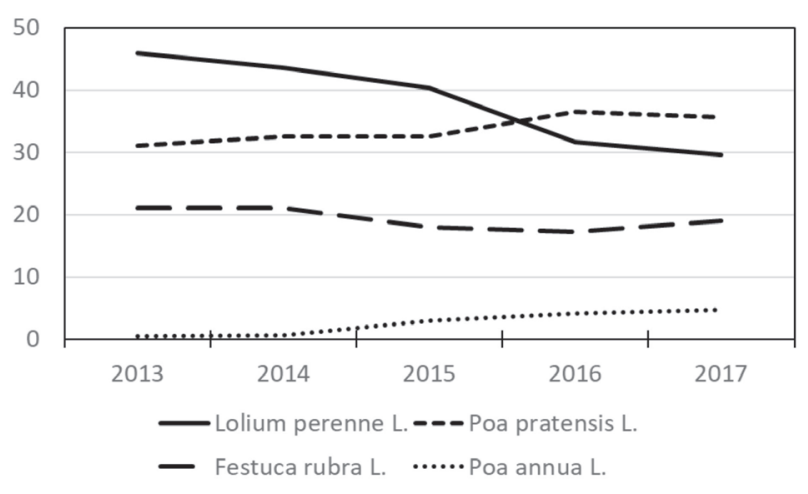

Fig. 2. Percentage share of grasses in the sward (\% DM).

(Fig. 2). Poa pratensis L. was the predominant species at the end of the five-year experiment. The proportion of Festuca rubra L. was close to the recommended seeding rate, whereas the proportion of Lolium perenne L. decreased at the end of the study. The proportion of the undesirable species Poa annиa L. exceeded the level recommended by DIN 18035-4 (1\%). The prevalence of dicotyledonous weeds, including Trifolium repens L. Medicago lupulina L., Plantago lanceolata L., Plantago media L., Bellis perennis L., Taraxacum officinale F.H. Wigg, Achillea millefolium L., Potentilla anserina L. and others, was low in the analyzed sward.

The high and stable proportion of Poa pratensis L. in the examined sward indicates that this species is particularly useful for establishing grass fields for various disciplines of professional sports [31]. The species is characterized by high persistence and high sward density, considerable overwintering success and high resistance to adverse habitat conditions, including variable water levels and temperatures [26, 27, 31, 34].

Lolium perenne L. is also widely used in sports fields and recreational areas [26]. In the current study, the decrease in the proportion of Lolium perenne L. in the analyzed sward could be attributed to drought and thermal stress (cold winters, spring frost, summer drought). The species is not highly resistant to low temperature, which decreases its persistence in northern regions $[28,35,36]$.

The high proportion of Poa annua L. in the examined sward could be explained by its high competitiveness in ecological succession. The plant reproduces by self-pollination, and it easily adapts to variable habitat conditions [37]. Poa аппиа L. is one of the most common weed species in high-quality sports fields in the USA [38].

In intensively exploited sports pitches, the decline in sward quality is a natural and widely observed phenomenon $[25,39-41]$. Bare patches in lawns are colonized by seedlings that develop from seeds from the soil seed bank, wind-dispersed seeds (seed rain) and seeds from vegetatively reproducing plants [42]. Previous research $[12,31,43]$ shows that the rate of plant growth and development is influenced by genotype, but it is also modified by changes in habitat conditions during the growing season. The presence of undesirable plant species in the sward can testify to intensive field use, excessive soil compaction and deterioration in the physical properties of the substrate.

\section{Conclusions}

1. An increase in soil compaction, a decrease in the sward's functional characteristics and changes in the species composition of grass were noted after five years of field use for various disciplines of professional sports.

2. The examined sward was characterized by varied overwintering success, high density (particularly in summer), green and fresh green color, very low prevalence of fungal diseases, and satisfactory or good visual merit.

3. The proportion of Lolium perenne L. decreased, whereas the proportion of the undesirable species Poa аппи $\mathrm{L}$. and dicotyledonous weeds increased in the analyzed sward.

4. The condition of the evaluated sward was influenced by loading (field exploitation), increased soil compaction, deterioration in the physicochemical properties of soil, as well as the applied maintenance treatments and weather conditions during the study.

\section{Conflict of Interest}

The authors declare no conflict of interest.

\section{References}

1. DOMAŃSKI P. Methods of studying economical value of cultivars of field crops. Agricultural plants. Turf (lawn) grasses. COBORU, Słupia Wielka, 1, 1998 [In Polish].

2. DIN 18035-4. Sportplätze - Rasenflächen. Deutsches Institut für Normung, Pforzheim, 2012.

3. PAWLUCZUK J., GRABOWSKI K. Impact of physical and chemical parameters of the subsoil on the botanical composition of sports field grass. J. Elem., 19 (2), 483, DOI: 10.5601/ jelem.2014.19.2.644. 2014.

4. GRABOWSKI K., PAWLUCZUK J., GRZEGORCZYK S., ŁACHACZ A., GRABOWSKA K. The physicochemical properties of soil and functional characteristics of sward on a grass airstrip. Pol. J. Environ. Stud., 26 (2), 605, DOI:10.15244/pjoes/66712, 2017.

5. TURGEON A.I. Turfgrass management. Pearson Prentice Hall. Phoenix Book. Tech., 1, 2005.

6. RUSSI L., ANNICCHIARICO P., MARTINIELLO P., TOMASONI C., PIANO E., VERONESI F. Turf quality of cool season grasses at low inputs: Reliability across years, seasons and sites of evaluation. Acta Hortic., 661, 387, 2004.

7. CANAWAY P.M. A comparison of different methods of establishment using see and sod on the cover and playing quality of for turf football. Journal of Sports, Turf Research Institute, 66, 9, 1990. 
8. STRAW CH.M., HENRY G.M., SHANNON J., THOMPSON J.J. Athletes' perceptions of within-field variability on natural turfgrass sports fields. Precision Agri., 20, 118, https://doi.org/10.1007/s 11119-018-9585-2, 2019.

9. FORD P.G., TWOMEY D.M. Moderating surface hardness and rotational traction of natural turf community - level football fields in drought. Acta Hortic. 1122, 111, 2016.

10. CARROW R.N. Surface organic matter in creeping bentgrass greens. Golf Course Mgmt., 75, 5, 96, 2004.

11. DIXON S. The science and engineering of sport surfaces. Routledge, Abingdon, 2015.

12. HUANG B., DA COSTA M., JIANG Y. Research advances in mechanisms of turfgrass tolerance to abiotic stresses. From Physiology to Molecular Biology. Crit. Rev. Plant Sci., 33, 2-3, 141, 2014.

13. KOSMALA M. Modern methods of establishment sport field grass. Przegląd Komunalny 8 (155), 43, 2004 [In Polish].

14. UEFA Pitch Quality Guidelines. Natural turf pitch management - 2018 edition. UEFA Headquarters, CH1260 Nyon 2, Switzerland, 2018. Available online: http:// www.uefa.com. (accessed on 24. Jan. 2020)

15. BEDNAREK R., DZIADOWIEC H., POKOJSKA U., PRUSINKIEWICZ Z. Soil-ecological investigations. Wyd. Naukowe PWN, Warszawa, 2004 [In Polish].

16. SAPEK A., SAPEK B. Methods of chemical analysis of organic soils. Mat. Instr. IMUZ Falenty 115, 81, 1997 [In Polish].

17. StatSoft Inc. 2018. Statistica (data analysis software system), version 13.1, 2018, (www.statsoft.com.)

18. Particle size distribution and textural classes of soils and mineral materials - Classification of Polish Society of Soil Science 2008. Rocz. Glebozn. - Soil Sc. Ann., 60, 2, 5, 2009.

19. SCHEFFER F., SCHACHTSCHABEL P. (Eds.) Lehrbuch der Bodenkunde, 15. Auflage, Springer Verlag, Berlin, 2002.

20. ZHU H., LI D. Using humus on golf course fairways to alleviate soil salinity problems. Horttechnology, 28, 284, DOI:10.21273/Horttech 03989-18, 2018.

21. KIM K. N. Effect of organic soil amendments on establishment vigor, seedling emergence and top growth in Kentucky bluegrass. Kor. J. Hort. Sci. Technol., 32, 2, 133, 2014.

22. ADAMS W.A., SAXON C. The occurrence and control of thatch in sport turf. Rasen Turf Gazeon, 3, 76, 1979.

23. Fertilizing recommendations. IUNG Puławy, 1, 1990 [In Polish].

24. CASLER M., GREOGS I., STIER I. Seeking snow mouldtolerant turfgrasses: Atough winter disease isn't so hard on some grasses. Golf Course Mgmt., 69, 49, 2001.

25. ANDERSON F.D., FLEMING P.R., SHERRATT P.J., SEVERN K. Novel field equipment for assessing the stability of natural and hybrid turf. Sports Eng., 21, 4, 321, 2018.

26. GRABOWSKI K., GRZEGORCZYK S., KWIETNIEWSKI H. Usefulness of 10 grasses mixtures for sowing on sport playing fields. Zesz. Nauk. UP Wroc., 545, 95, 2006 [In Polish].

27. KOH S.G., TAE H.S., RYN C.H. Effect of animal organic soil amendment on growth of Korean lawn grass and Kentucky bluegrass. Kor. J. Turfgrass Sci., 20, 33, 2006.
28. THOROGOOD D. Perennial ryegrass (Lolium perenne L.). Turfgrass Biology Genetics and Breeding, 7, 75, 2003.

29. LAUDAŃSKI Z., PROŃCZUK M., PROŃCZUK M. Proposition of turf characters synthesis for assessment of Festuca ssp. cultivars value. Biul. IHAR, 233, 181, 2004 [In Polish].

30. WOLSKI K., TALAR-KRASA M., DRADRACH A., SZYMURA M., BIERNACIK M., ŚWIERSZCZ S. The assessment of usable features of football pitch turf on the example of KS AZS Wrocław. Grassland Science in Poland, 18, 241, 2015.

31. BREDE D. Multi-way Kentucky bluegrass blends and their effect on turfgrass quality. Acta Hortic., 783, 19, 2008.

32. DIESBURG K.L., CHRISTIANS N.E., MOORE R., BRANHAM B., DANNEBERGER T.K., REICHER Z.I., VOIGT T., MINNER D.D., NEWMAN R. Species for lowinput sustainable turf in the U.S. Upper Midwest. Agron. J., 89 (4), 690, 1997.

33. DOUGLASS I.T., CRAWFORD C.E. The response of ryegrass sward to wheel traffic and applied nitrogen. Grass Forage Sci., 48, 91, 1993.

34. PATTON A.I., BRAUN R.C., SCHORTGEN G.P., WEISENBERGER D.Y., BRANHAM B.E., SHARP B., SOUSEK M.D., GAUSSION R. E., REICHER Z.I. Longterm efficacy of Annual Bluegrass control strategies on golf course putting greens. Crop Forages Turfgrass Management 5:180068, DOI: $10.2134 / \mathrm{cftm} 2018.09 .0068$, 2019.

35. IRABA A., CASTONGUAY Y., BERTRAND A., FLOYD D.J., CLOUTIER I., BELZILE F. Characterization of populations of turf-type Perennial Ryegrass recurrently selected of superior freezing tolerance. Crop. Sci., 53, 2225. DOI:10.2135/cropsci 2013.02.0100, 2013.

36. ORCHARD J.W., CHIVERS I., ALDOUS D., BENNELL K., SEWARD H. Rye grass is associated with fewer noncontact anterior cruciate ligament injuries than Bermuda grass. Br. J. Sports Med., 39, 704, 2005.

37. CHEN Y., PETTERSEN T., KVALBEIN A., AAMILD T. S. Playing quality, growth rate, thatch accumulation and tolerance to moss and annual bluegrass invasion as influenced by irrigation strategies on red fescue putting greens, J. Agron. Crop. Sci., 204, 185, 2018. https://doi. org/10.1111/jac.12246.

38. BEARD I.B., RICKE P.E., TURGEON A.I., VARGAS I.M. Annual bluegrass (Poa annua L.) description, adaptation, culture and control. Michigan Agr. Expt. Res. Rept., 352, 1978.

39. FOLLIS C.C., ANDERSON S.H., FRESENBURG B.S., ERVIN E.H. Evaluation of sand-soil-compost root zones developed for athletic fields. Acta Hortic., 783, 97, 2008.

40. MINNER D.D., BUTLER I.D. Drought tolerance of cool season turf grasses. Proc. of the Fifth Int. Turfgrass Res. Conf. Avignon, France, 1-15.07.1985, INRA, 199, 1985.

41. THANHEISER S.Y., GRASHEY-JANSEN S., ARMBRUSTER G. Hardness measurement of natural and hybrid turf soccer fields. Sports Eng., 21, 367, 2018.

42. PAKEMAN R.I., SMALL I.L. The role of the seed bank, seed rain and the timing of disturbance in gap regeneration. J. Veg. Sci., 16 (1), 121, 2005.

43. GIBBS R.I., ADAMS W., BAKER S. Changes in soil physical properties of different construction methods for soccer-pitches under intensive use. Int. Turfgrass Soc. Turfgrass Soc. Res. I., 7, 413, 1993. 